\title{
IS THERE A DIFFERENCE IN THE CAPITAL STRUCTURE INTER SECTOR?
}

\author{
Arief Yulianto \\ Department of Management, Faculty of Economics, Universitas Negeri Semarang, Semarang, \\ Indonesia \\ Angga Pandu Wijaya \\ Department of Management, Faculty of Economics, Universitas Negeri Semarang, Semarang, \\ Indonesia
}

Article DOI: https://doi.org/10.36713/epra5837

\begin{abstract}
This study aims to examine the capital structure of all industrial sectors in Indonesia. The test data is carried out using sources from the Indonesia Stock Exchange in 2009. The test results show that there are differences in the capital structure between industries in Indonesia. This research can be used as a reference in determining strategies for policy makers.
\end{abstract}

KEYWORDS: Capital Structure; Industry; Debt; Tax

\section{INTRODUCTION}

The debate regarding the capital structure decision starts from (Modigliani \& Miller, 1958), which states that it has nothing to do with firm value. Then it is developed in the company model to choose debt in the capital structure if there is a greater benefit in tax savings compared to bankruptcy costs (Miller, 1977). There are still differences and disagreements between managers to determine their relationship to firm value. When a company chooses to do debt, the implication is that it raises operating expenses. When companies choose to incur debt, the tax burden is reduced. Another method of determining the capital structure is to follow the capital structure of the industry (similar companies, which are then averaged) or other companies (one or two) that have the same business risk.

If a company has a capital structure that deviates too much from the industry average, the market (outsiders) will immediately question the cause. These deviations don't have to mean bad. If most companies use a conservative capital structure, the industry average for capital structure will appear smaller. Although it is likely that the optimal debt ratio could be higher than the industry average. Therefore, financial managers must prepare strong and convincing arguments if they want to use a capital structure that deviates significantly from the industry average. The coverage ratio is often used by lenders and rating agencies to assess the risk of bankruptcy. . Competition in the business world is getting tougher,Capital structure decisions are an important component, these conditions require companies to be superior in competition to achieve company goals. The company has a goal of being able to increase the prosperity of shareholders and achieve optimal profits. In meeting these objectives, it is necessary to make the right decisions from company management in making funding decisions. The company's financial funding decisions affect the company's activities. Capital is needed by every company, for operational funds and for company expansion. The company must determine the amount of capital needed to fulfill or finance the company (Maryanti, 2016)

The phenomenon until now it is still a puzzle, this study aims to fill the gap whether the choice of capital structure is determined by the industrial sector. Different industrial sectors have a greater variation in capital structure, which is due to the different characteristics of the business scope (Das \& Roy, 2007). They explained that technology-based companies have debt on a more varied capital structure, apart from the company's limitation on 
bank credit. Indonesia is a country based on a bank-market system, not a capital market system (Warjiyo, 2015), so that the supply of credit can encourage a bigger debt increase in the capital structure. Therefore, the aim of this research is to find out whether there are differences in debt in the capital structure across sectors or different industries. In an increasingly competitive business world, companies must be able to develop and create new values or innovations in order to survive in the competition, among others by creating value through improving business processes. The company is driven to have an advantage over its competitors. In carrying out its business activities, profit is the main goal that must be achieved by every company, with these advantages, the company's capital and assets will increase which in turn will increase the company's ability to carry out its operations. The benefits obtained are not only determined by the company's own ability, but also by the level of competition. Every company must be able to create added value for its company in order to survive and be able to outperform its competitors, so that it becomes a superior company.

This paper is divided into 5 parts, namely the second part is the literature review, the third is the research method. Furthermore, section four discusses the findings and discussion, and closes in the fifth section.

\section{LITERATURE REVIEW}

The fact that there are relatively different external funding requirements can be attributed to the varied industrial developments and the different developments in the financial market sector (Rajan \& Zingales, 1996). Assuming a perfect capital market, they have identified the financing needs of a larger financial sector due to the demand for industrial technology. Since the need for external funds indicates the desired amount of investment that cannot be financed through internal cash flows; the composition of external funds in the capital structure is important. The emergence of an arbitration process that will make the share price (company value) that does not use debt or that uses debt, ultimately the same. The arbitrage process arises because investors always prefer investments that require less funds but provide the same net income with the same level of risk (Morniaga, 2013). A good capital structure will have an impact on the company and indirectly the company's financial position will increase and the company's value will be high. Mistakes in managing the capital structure will result in large debt, and this will also increase financial risk because the company's inability to pay interest and debt expenses, so the company's value will decrease (Dewi \& Sudiartha, 2017).

The pecking order theory states that companies prefer the use of internal rather than external funds in order to finance their business development. If the internal source of funding originating from financial slack is insufficient, external funding sources are used. If an external source of funding is needed, the main choice will be taken from the use of debt by issuing bonds. Agency fees play an important role in funding decisions because of the possible conflicts between shareholders and bond / debt holders. If the company is experiencing financial difficulties, shareholders can encourage management to take action, which may have an impact on shifting financing from bond / debt holders to shareholders. Bond / debt holders who are aware of this will demand a higher rate of return if a potential transfer of wealth is seen. However debt and interest payments can reduce agency conflicts between shareholders and managers. Bond / debt holders have the legal right to claim compensation if management fails to pay interest when due, so that management will face the possibility of losing their jobs if they fail to run the company efficiently.

Costs that will arise as a result of fulfilling company capital can be either an explicit cost or an implicit cost that must be paid by the company or the profits hinted at by investors. Opportunity cost causes the incidence of capital costs that are not cash costs. Companies need to be careful in determining the optimal capital structure used by companies, with the aim of reducing liquidity risk. Profitability has a negative effect on structure Company Capital. This means that if the profitability increases then there will be a decline in the Company's Capital Structure. The opposite applies when profitability decreases, so there will be an increase in the company's capital structure the building construction sub-sector on the IDX. High internal company funds obtained from profitability so as to be able to fund company investment with a lower risk, the company will tend to use internal versus external funding (Prastika and Candradewi, 2019)

Hypothesis: there are differences in the capital structure between industries in Indonesia

\section{METHOD}

The data used in this research is the debt and equity ratio which describes the proposition of using external data on companies listed on the Indonesia Stock Exchange in 2009. Data obtained are 127 observation units, with the distribution as shown in Figure 1. 


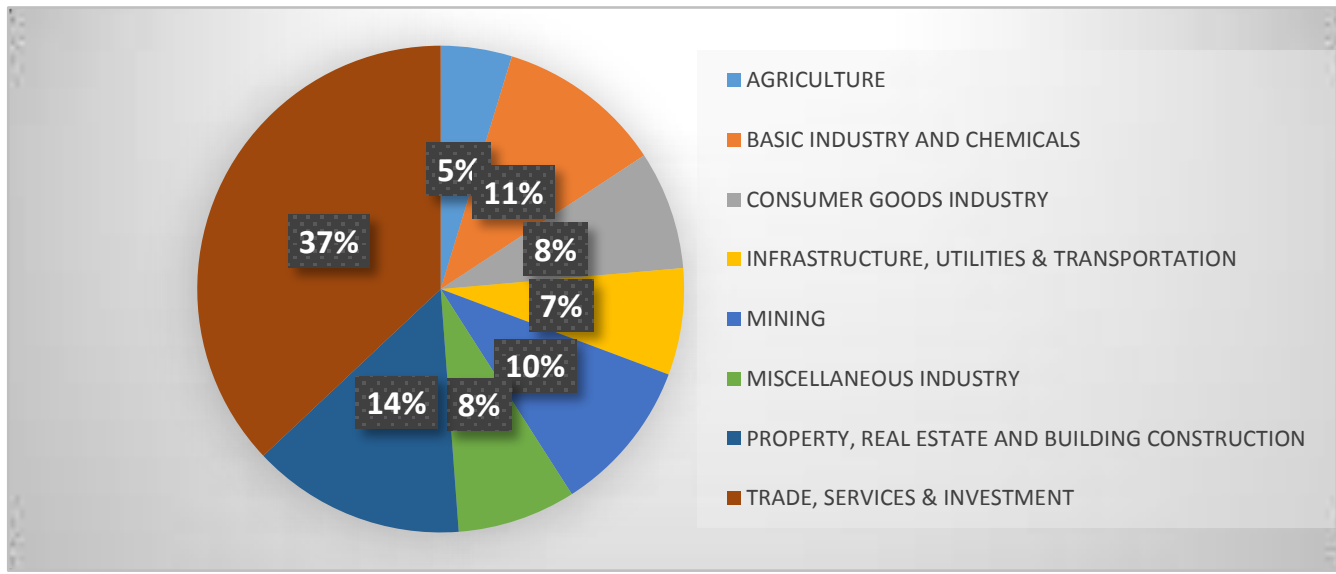

Figure 1. Indonesia Stock Exchange Sector Distribution

The results of the prerequisite test showed that the data was not normal, so the test was carried out with non-parametric statistics, namely the Kruskal-Wallis as represented on figure 2 .

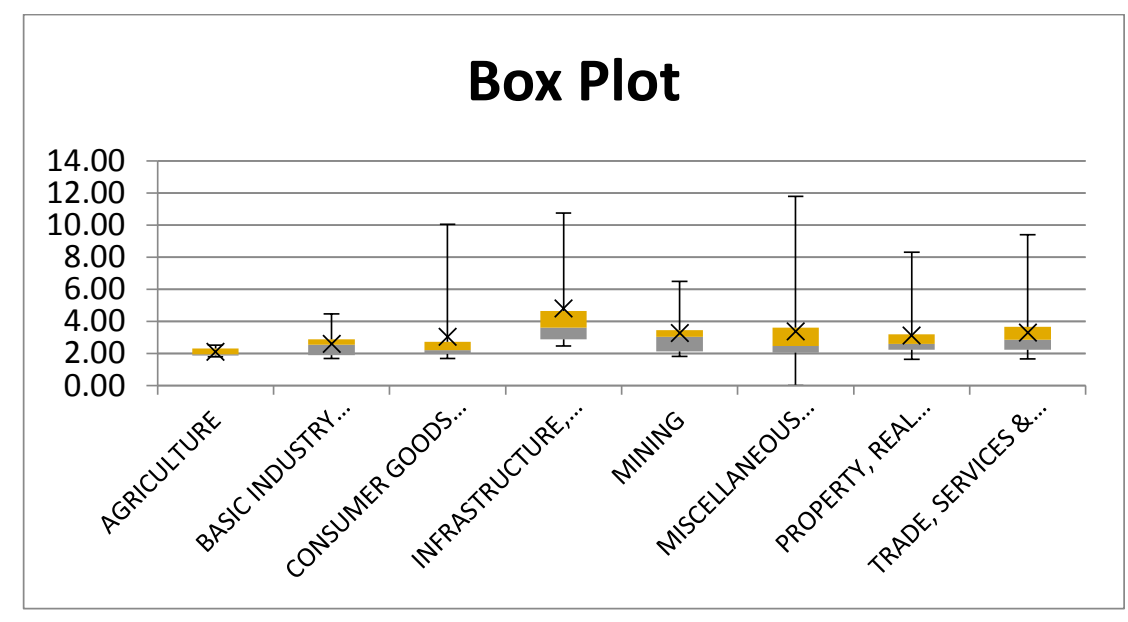

Figure 2. Kruskall-Wallis Result

Research result in Table 1 and Table 2 show that the variation in all sectors has positive skewness, meaning that most of the DER data are on the left side of the median. The company is trying to maintain a low DER ratio in all sectors. However based on kurtosis it is known that The $\mathrm{KW}$ test results show that the $\mathrm{p}$ value is smaller than 0.05 , which means that Ho is rejected and $\mathrm{Ha}$ is accepted.
The results show that there are differences in the capital structure between sectors on the Indonesia Stock Exchange. These results are consistent with previous research (Rajan \& Zingales, 1996). In infrastructure companies, using debt is greater than that of others, on the other hand, in agriculture, debt is smaller than equity. 
Table 1. Descriptive and Normality Research Result

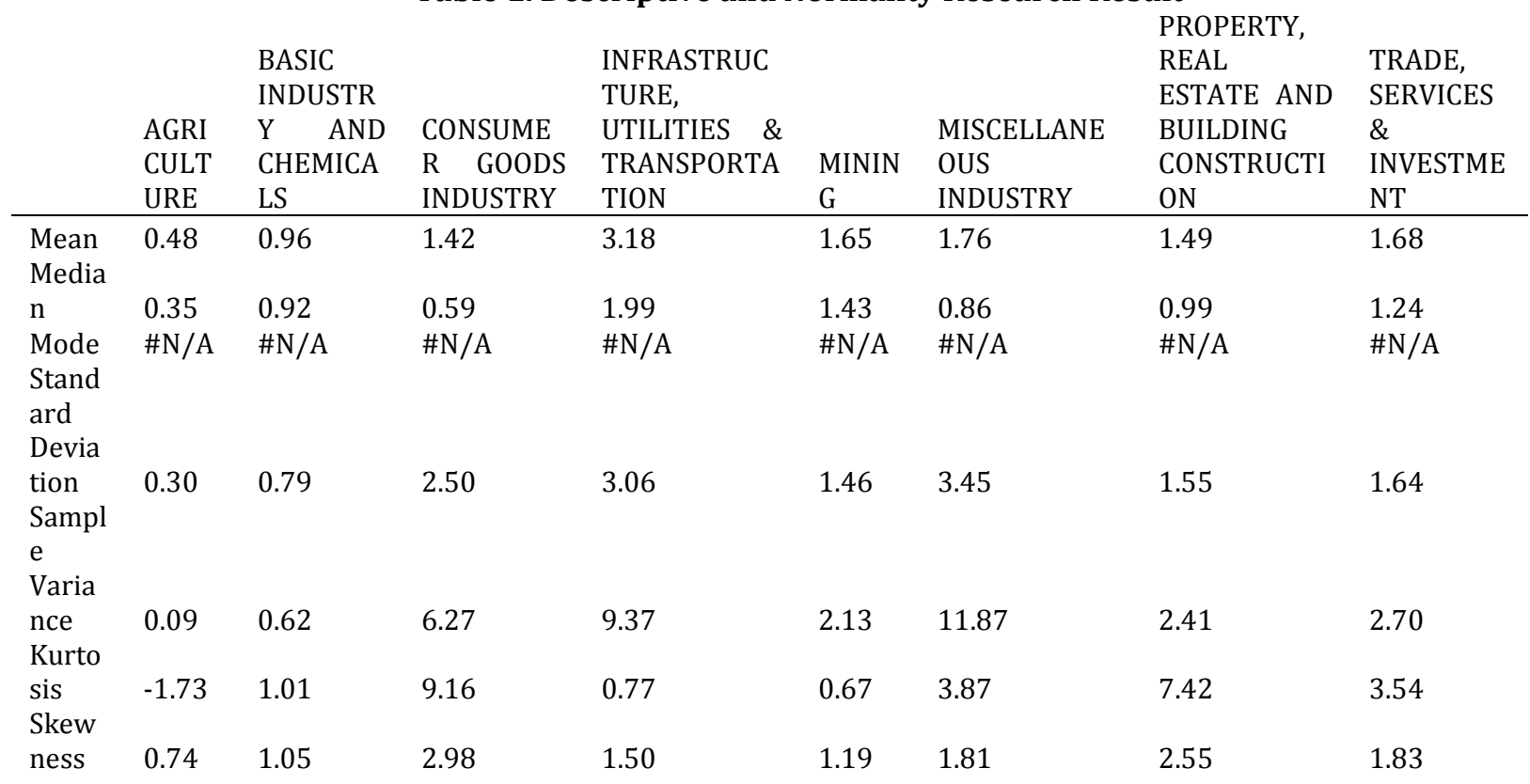

Table 2. Research Result

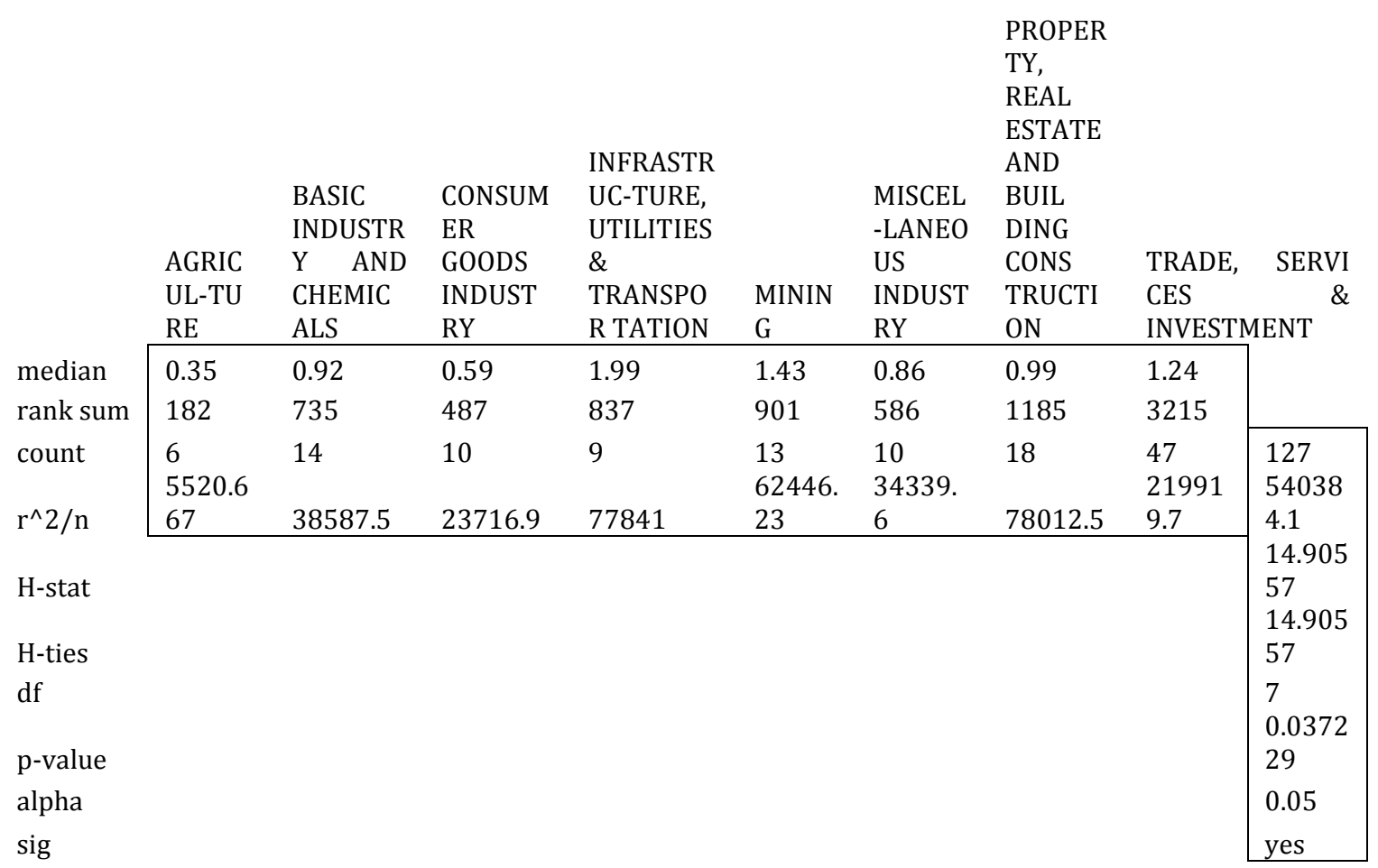

\section{DISCUSSION}

The difference in debt in the capital structure can be caused by weak good governance in Indonesia, so that shareholders and managers collaborate to use debt for their interests (Harijono \& Tanewski, 2012). Managers will act on their interests, namely being opportunistic in nature so that they are detrimental to shareholders or acting on the interests of shareholders that are detrimental to the interests of debtholders ( $\mathrm{La}$ Rocca et al., 2007). Or other causes such as future growth opportunities are often constrained by limited funds, resulting in over or underinvestment. 


\section{SUGGESTION}

Different sector characteristics cause the use of debt in the capital structure to vary. The future growth opportunities will determine the use of this debt. When the capital structure is at optimal conditions, managers can accept or refuse to explore these growth opportunities.

\section{BIBLIOGRAPHY}

1. Das, S., \& Roy, M. (2007). Inter-Industry Differences in Capital Structure: The Evidence from India. Finance India, 21(2), 517.

2. Dewi, D. A. I. Y. M., \& Sudiartha, G. M. (2017). Pengaruh Profitabilitas, Ukuran Perusahaan, Dan Pertumbuhan Aset Terhadap Struktur Modal Dan Nilai Perusahaan. E-Jurnal Manajemen Universitas Udayana, 6(4).

3. Harijono, H., \& Tanewski, G. (2012). Does Legal Transplantation Work? The Case of Indonesian Corporate Governance Reforms. Journal of Indonesian Economy and Business, 27(1), 73-97. https://doi.org/10.2139/ssrn.1772808

4. La Rocca, M., La Rocca, T., \& Cariola, A. (2007). Overinvestment and Underinvestment Problems: Determining Factors, Consequences and Solutions. Corporate Ownership and Control, 5(1), 79-95. https://doi.org/10.22495/cocv5ilp7

5. Moniaga, F. (2013). Struktur modal, profitabilitas dan struktur biaya terhadap nilai perusahaan industri keramik, porcelen dan kaca periode 2007-2011. Jurnal EMBA: Jurnal Riset Ekonomi, Manajemen, Bisnis dan Akuntansi, 1(4).

6. Maryanti, E. (2016). Analisis Profitabilitas, Pertumbuhan Perusahaan, Pertumbuhan Penjualan dan Struktur Aktiva terhadap Struktur Modal pada Perusahaan Sektor Industri Barang Konsumsi yang terdaftar di Bursa Efek Indonesia (Studi Empiris pada Perusahaan Manufaktur yang Terdaftar di Bursa Efek Indonesia Tahun 2012-2014). Riset Akuntansi dan Keuangan Indonesia, 1(2), 143-151.

7. Miller, M. H. (1977). Debt and Taxes. Journal of Finance, XXXII(2), 261-275.

8. Modigliani, F., \& Miller, M. H. (1958). The Cost of Capital, Corporation Finance and the Theory of Investment. The American Economic Review, 48(3),

https://doi.org/10.1136/bmj.2.3594.952

9. Prastika, N. P. Y., \& Candradewi, M. R. (2019). Pengaruh Profitabilitas, Struktur Aktiva, Dan Likuiditas Terhadap Struktur Modal Perusahaan Subsektor Konstruksi Bangunan Di BEI. E-Jurnal Manajemen, 8(7), 4444-4473.

10. Rajan, R. G., \& Zingales, L. (1996). Financial dependence and growth: Further evidence. American Economic Review, 16(3), 325-330. https://doi.org/10.1080/13504850601018452

11. Warjiyo, P. (2015). Indonesia: Changing Patterns of Financial Intermediation and Their Implications for Central Bank Policy. In BIS Paper (Issue 83). 